\title{
Konsep dan Desain Negara Kesejahteraan (Welfare State)
}

\author{
Oman Sukmana* \\ osukmana@ymail.com
}

\begin{abstract}
Abstrak
Negara kesejahteraan (welfare state) dianggap sebagai jawaban yang paling tepat atas bentuk keterlibatan negara dalam memajukan kesejahteraan rakyat. Keyakinan ini diperkuat oleh munculnya kenyataan empiris mengenai kegagalan pasar (market failure) dan kegagalan negara (state failure) dalam meningkatkan kesejahteraan rakyat. Menurut Goodin (1999; dalam Simarmata, 2008: 19) negara kesejahteraan sering diasosiasikan dengan proses distribusi sumber daya yang ada kepada publik, baik secara tunai maupun dalam bentuk tertentu (cash benefits or benefits in kind). Konsep kesejahteraan juga terkait erat dengan kebijakan sosialekonomi yang berupaya untuk mewujudkan kesejahteraan rakyat secara umum. Beberapa bidang yang paling mendesak untuk diperhatikan dalam kebijakan kesejahteraan adalah masalah pendidikan, kesehatan dan penyediaan lapangan kerja. Secara umum suatu negara bisa digolongkan sebagai negara kesejahteraan jika mempunyai empat pilar utamanya, yaitu: (1) social citizenship; (2) full democracy; (3) modern industrial relation systems; dan (4) rights to education and the expansion of modern mass educations systems
\end{abstract}

Kata kunci : negara kesejahteraan, kegagalan pasar, kegagalan negara

\begin{abstract}
Welfare state is considered as the most appropriate response on the form of state involvement in advancing the welfare of the people. This belief was reinforced by the emergence of empirical facts about the failure of the market (market failure) and the failure of the state (state failure) in improving people's welfare. According to Goodin (1999; in Simarmata, 2008: 19) the welfare state is often associated with the distribution of existing resources to the public, either in cash or in the form of certain (cash benefits or benefits in kind). The concept of well-being are closely linked to socio-economic policy of working to realize the people's welfare in general. Some of the most urgent areas for attention in welfare policy is a matter of education, health and employment. In general, a country can be classified as a welfare state if it has four main pillars, namely: (1) social citizenship; (2) full democracy; (3) modern industrial relations systems; and (4) the rights to education and the expansion of modern mass Educations systems.
\end{abstract}

Keywords : market failure, state failure, welfare state

\section{Pendahuluan}

Dewasa ini, wacana mengenai negara kesejahteraan (welfare state) menjadi pusat perhatian khususnya di kalangan politisi dan akademisi. Secara khusus, dalam Musyawarah Luar Biasa (Munaslub) Partai Golkar di Bali pada tanggal 13-15 Mei 2016, isu tentang Negara Kesejahteraan (Welfare State) diangkat sebagai isu utama dalam debat kandidat Caketum Partai Golkar.

\footnotetext{
*Korespondensi : Oman Sukmana, Prodi Ilmu Kesejahteraan Sosial FISIP UMM, Jl Raya Tlogomas 246 Malang (0341) 464318 Fax (0341) 460435.
} 
Besarnya perhatian atas isu negara kesejahteraan (welfare state), mengingat bahwa negara kesejahteraan (welfare state) dianggap sebagai jawaban yang paling tepat atas bentuk keterlibatan negara dalam memajukan kesejahteraan rakyat. Keyakinan ini diperkuat oleh munculnya kenyataan empiris mengenai kegagalan pasar (market failure) dan kegagalan negara (state failure) dalam meningkatkan kesejahteraan rakyat. Menurut Myles dan Quadagno (2002: 34), pada dekade tahun 1970-an studi kontemporer tentang negara kesejahteraan modern mendapatkan banyak perhatian, baik dari kalangan sejarawan (bistorians), ilmuwan politik (political scientists), dan ilmuwanilmuwan sosial lainnya.

Membangun negara kesejahteraan, menjadi obsesi banyak negara baru terutama di Asia yang merdeka setelah Perang Dunia II. Beberapa negara seperti Korea Selatan, Taiwan, dan Singapura, telah cukup berhasil membangun negara kesejahteraannya (Triwibowo \& Bahagio, 2006:xvii). Demikian pula, negara Kesatuan Republik Indonesia, sebagaimana diamanatkan dalam Undang-Undang Dasar 1945, didesain sebagai Negara Kesejahteraan (welfare state). Menurut Pierson (2007:9), kata kesejahteraan (welfare) di dalamnya paling tidak mengandung tiga subklasifikasi, yakni: (1) Social welfare, yang mengacu kepada penerimaan kolektif kesejahteraan; (2) Economic welfare, yang mengacu kepada jaminan keamanan melalui pasar atau ekonomi formal; dan (3) State welfare, yang mengacu kepada jaminan pelayanan kesejahteraan sosial melalui agen dari negara. Negara Kesejahteraan (welfare state) secara singkat didefinisikan sebagai suatu negara dimana pemerintahan negara dianggap bertanggung jawab dalam menjamin standar kesejahteraan hidup minimum bagi setiap warga negaranya.

Asumsi yang kuat bahwa negara Kesatuan Republik Indonesiadidesain sebagai Negara Kesejahteraan (welfare state) dapat dilacak dari bunyi pembukaan UUD 1945 bahwa "Pemerintah melindungi segenap bangsa dan seluruh tumpah darah, memajukan kesejahteraan umum dan mencerdaskan kehidupan bangsa". Selain itu beberapa pasal dalam UUD 1945 mencerminkan pula nilai dasar dari Negara Kesejahteraan (welfare state), seperti:pasal 27 (2) “Tiap-tiap warga negara berhak atas pekerjaan dan penghidupan yang layak bagi kemanusiaan"; Pasal 28A "Setiap orang berhak untuk hidup serta berhak mempertahankan hidup dan kehidupannya; demikian pula pada pasal 28B, 28C, 28H, 31, 33, dan pasal 34. 
Apa sesungguhnya konsep Negara Kesejahteraan (welfare state)? Dan bagaimanakah desain Negara Kesejahteraan (welfare state) itu? Uraian makalah ini akan mencoba menjelaskan kedua hal tersebut.

\section{Konsep Negara Kesejahteraan (Welfare State)}

Sebenarnya gagasan tentang Negara Kesejahteraan (wvelfare state)bukanlah suatu gagasan yang baru. Ide tentang Negara Kesejahteraan (welfare state)sudah lahir sejak sekitar abad ke-18. Menurut Bessant, Watts, Dalton dan Smith (2006), ide dasar negara kesejahteraan beranjak dari abad ke-18 ketika Jeremy Bentham (1748-1832) mempromosikan gagasan bahwa pemerintah memiliki tanggung jawab untuk menjamin the greatest happiness (atau welfare) of the greatest number of their citizens. Bentham menggunakan istilah 'utility' (kegunaan) untuk menjelaskan konsep kebahagiaan atau kesejahteraan. Berdasarkan prinsip utilitarianisme yang ia kembangkan, Bentham berpendapat bahwa sesuatu yang dapat menimbulkan kebahagiaan ekstra adalah sesuatu yang baik. Sebaliknya, sesuatu yang menimbulkan sakit adalah buruk. Menurutnya, aksi-aksi pemerintah harus selalu diarahkan untuk meningkatkan kebahagian sebanyak mungkin orang. Gagasan Bentham mengenai reformasi hukum, peranan konstitusi dan penelitian sosial bagi pengembangan kebijakan sosial membuat ia dikenal sebagai "bapak negara kesejahteraan" (father of welfare states).

Sementara pada tahun 1850-an di Prusia konsep Negara Kesejahteraan (welfare state) dirintis oleh Otto Von Bismarck (Triwibowo \& Bahagio, 2006:xvi). Di masa lalu, di Eropa dan Amerika, gagasan tentang Negara Kesejahteraan (welfare state) sempat berbenturan dengan konsepsi negara liberal kapitalistik. Namun ternyata benturan kedua gagasan besar tersebut telah menghasilkan negara-negara makmur, terutama di Eropa Barat dan Amerika Utara, dimana rakyatnya hidup dengan sejahtera. Rakyat di negara-negara tersebut bisa menikmanti pelayanan dari negara di bidang kesehatan dan jaminan hari tua dengan program asuransi kesehatan dan pensiun, sekolah gratis, dan sebagainya. Di Jerman, misalnya, warga negara mendapatkan jaminan sekolah gratis hingga tingkat Universitas, memperoleh jaminan penghidupan yang layak dari sisi pendapatan dan standar hidup, mendapatkan pelayanan sistem transportasi yang murah dan efisien, dan orang yang menganggur menjadi tanggungan negara. Semua layanan negara tersebut sebenarnya dibiayai 
sendiri oleh masyarakatnya yang telah menjadi semakin makmur melalui sistem asuransi dan perpajakan, dengan orientasi utamanya peningkatan kualitas sumberdaya manusia dari warga negaranya (buman investment).

Tokoh lain yang turut mempopulerkan sistem negara kesejahteraan adalah Sir William Beveridge (1942) dan T.H. Marshall (1963). Di Inggris, dalam laporannya mengenai Social Insurance and Allied Services, yang terkenal dengan nama Beveridge Report, Beveridge menyebut want, squalor, ignorance, disease dan idleness sebagai 'the five giant evils' yang harus diperangi (Spicker, 1995; Bessant, et al, 2006). Dalam laporan itu, Beveridge mengusulkan sebuah sistem asuransi sosial komprehensif yang dipandangnya mampu melindungi orang dari buaian hingga liang lahat (from cradle to grave). Pengaruh laporan Beveridge tidak hanya di Inggris, melainkan juga menyebar ke negara-negara lain di Eropa dan bahkan hingga ke AS dan kemudian menjadi dasar bagi pengembangan skema jaminan sosial di negaranegara tersebut. Sayangnya, sistem ini memiliki kekurangan. Karena berpijak pada prinsip dan skema asuransi, ia tidak dapat mencakup resiko-resiko yang dihadapi manusia terutama jika mereka tidak mampu membayar kontribusi (premi). Asuransi sosial gagal merespon kebutuhan kelompok-kelompok khusus, seperti orang cacat, orang tua tunggal, serta mereka yang tidak dapat bekerja dan memperoleh pendapatan dalam jangka waktu lama. Manfaat dan pertanggungan asuransi sosial juga seringkali tidak adekuat, karena jumlahnya kecil dan hanya mencakup kebutuhan dasar secara minimal.

Dalam konteks kapitalisme, Marshall berargumen bahwa warga negara memiliki kewajiban kolektif untuk turut memperjuangkan kesejahteraan orang lain melalui lembaga yang disebut negara (Harris, 1999; dalam Suharto, 2006). Ketidaksempurnaan pasar dalam menyediakan pelayanan sosial yang menjadi hak warga negara telah menimbulkan ketidakadilan. Ketidakadilan pasar harus dikurangi oleh negara untuk menjamin stabilitas sosial dan mengurangi dampak-dampak negatif kapitalisme. Marshall melihat sistem negara kesejahteraan sebagai kompensasi yang harus dibayar oleh kelas penguasa dan pekerja untuk menciptakan stabilitas sosial dan memelihara masyarakat kapitalis. Pelayanan sosial yang diberikan pada dasarnya merupakan ekspresi material dari hak-hak warga negara dalam merespon konsekuensikonsekuensi kapitalisme. 
Spicker (Suharto, 2005:50) berpendapat bahwa negara kesejahteraan dapat didefinisikan sebagai sebuah sistem kesejahteraan sosial yang memberi peran lebih besar kepada negara (pemerintah) untuk mengalokasikan sebagian dana publik demi menjamin terpenuhinya kebutuhan dasar warganya. Sementara, Husodo menyatakan bahwa Negara Kesejahteraan (welfare state) secara singkat didefinisikan sebagai suatu negara dimana pemerintahan negara dianggap bertanggung jawab dalam menjamin standar kesejahteraan hidup minimum bagi setiap warga negaranya (Triwibowo \& Bahagijo, 2006: xv).

Menurut Esping-Anderson (Triwibowo \& Bahagijo, 2006; 9), negara kesejahteraan pada dasarnya mengacu pada peran negara yang aktif dalam mengelola dan mengorganisasi perekonomian yang di dalamnya mencakup tanggung jawab negara untuk menjamin ketersediaan pelayanan kesejahteraan dasar dalam tingkat tertentu bagi warga negaranya. Secara umum suatu negara bisa digolongkan sebagai negara kesejahteraan jika mempunyai empat pilar utamanya, yaitu: (1) social citizenship; (2) full democracy; (3) modern industrial relation systems; dan (4) rights to education and the expansion of modern mass educations systems. Keempat pilar ini dimungkinkan dalam negara kesejahteraan karena negara memperlakukan penerapan kebijakan sosial sebagai penganugerahan hak-hak sosial (the granting of social rights) kepada warganya. Hak-hak sosial tersebut mendapat jaminan seperti layaknya hak atas properti, tidak dapat dilanggar (inviolable), serta diberikan berdasar basis kewargaan (citizenship) dan bukan atas dasar kinerja atau kelas.

Dalam garis besar, negara kesejahteraan menunjuk pada sebuah model ideal pembangunan yang difokuskan pada peningkatan kesejahteraan melalui pemberian peran yang lebih penting kepada negara dalam memberikan pelayanan sosial secara universal dan komprehensif kepada warganya. Di Inggris, konsep welfare state dipahami sebagai alternatif terhadap the Poor Law yang kerap menimbulkan stigma, karena hanya ditujukan untuk memberi bantuan bagi orang-orang miskin (Suharto, 1997; Spicker, 2002) ${ }^{1}$. Berbeda dengan sistem dalam the Poor Law, negara kesejahteraan difokuskan pada penyelenggaraan sistem perlindungan sosial yang melembaga bagi setiap orang sebagai cerminan dari adanya hak kewarganegaraan (right of citizenship), di satu pihak, dan kewajiban negara (state obligation), di pihak lain. Negara kesejahteraan ditujukan untuk menyediakan pelayanan-pelayanan sosial bagi 
seluruh penduduk - orang tua dan anak-anak, pria dan wanita, kaya dan miskin-, sebaik dan sedapat mungkin. Ia berupaya untuk mengintegrasikan sistem sumber dan menyelenggarakan jaringan pelayanan yang dapat memelihara dan meningkatkan kesejahteraan (well-being) warga negara secara adil dan berkelanjutan.

Negara merupakan integrasi dari kekuasaan politik, negara adalah organisasi pokok dari kekuasaan politik. Negara adalah alat (agency) dari masyarakat yang mempunyai kekuasaan untuk mengatur hubungan-hubungan manusia dalam masyarakat dan menertibkan gejala-gejala kekuasaan dalam masyarakat. Manusia hidup dalam suasana kerjasama, sekaligus suasana antagonis dan penuh pertentangan. Negara adalah organisasi yang dalam sesuatu wilayah dapat memaksakan kekuasaannya secara sah terhadap semua golongan kekuasaan lainnya dan yang dapat menetapkan tujuan-tujuan dari kehidupan bersama itu. Negara menetapkan cara-cara dan batas-batas sampai di mana kekuasaan dapat digunakan dalam kehidupan bersama, baik oleh individu, golongan atau asosiasi, maupun oleh negara sendiri. Dengan demikian negara dapat mengintegrasikan dan membimbing kegiatan-kegiatan sosial dari penduduknya ke arah tujuan bersama.

Dalam rangka ini boleh dikatakan bahwa negara mempunyai tugas: (a) mengendalikan dan mengatur gejala-gejala kekuasaan yang asosial, yakni yang bertentangan satu sama lain, supaya tidak menjadi antagonis yang membahayakan; dan (b) mengorganisir dan mengintegrasikan kegiatan manusia dan golongangolongan ke arah tercapainya tujuan-tujuan dari masyarakat seluruhnya. Negara menentukan bagaimana kegiatan-kegiatan asosiasi-asosiasi kemasyarakatan disesuaikan satu sama lain dan diarahkan kepada tujuan nasional. Pengendalian ini dilakukan berdasarkan sistem hukum dan dengan perantaraan pemerintah beserta segala alat perlengkapannya. Kekuasaan negara mempunyai organisasi yang paling kuat dan teratur, maka dari itu semua golongan atau asosiasi yang memperjuangkan kekuasaan harus dapat menempatkan diri dalam rangka ini (Budiardjo, 2008: 48).

Negara dapat dipandang sebagai asosiasi manusia yang hidup dan bekerjasama untuk mengejar beberapa tujuan bersama. Dapat dikatakan bahwa tujuan terakhir setiap negara ialah menciptakan kebahagiaan bagi rakyatnya (bonum publicum, common good, common wealth). Menurut Roger H. Soltau (Budiardjo, 2008:54) tujuan negara adalah memungkinkan rakyatnya berkembang serta menyelenggarakan 
daya ciptanya sebebas mungkin (The freest possible development and creative self-expression of its members). Sedangkan menurut Harold J. Laski (Budiarjo, 2008: 55) menyatakan bahwa tujuan negara adalah menciptakan keadaan di mana rakyat dapat mencapai keinginan-keinginan mereka secara maksimal (Creation of those conditions under which the members of the state may attain the maximum satisfaction of their desires).

Selanjutnya Budiardjo (2008: 55-56) menyatakan bahwa terlepas dari ideologinya, setiap negara menyelenggarakan beberapa minimum fungsi yang mutlak perlu, yaitu: (1) Melaksanakan penertiban (law and order); untuk mencapai tujuan bersama dan mencegah bentrokan-bentrokan dalam masyarakat, negara harus melaksanakan penertiban, dapat dikatakan bahwa negara bertindak sebagai stabilisator; (2) Mengusahakan kesejahteraan dan kemakmuran rakyatnya. Dewasa ini fungsi ini sangat penting terutama bagi negara-negara baru; (3) Pertahanan. Hal ini diperlukan untuk menjaga kemungkinan serangan dari luar. Untuk itu negara dilengkapi dengan alat-alat pertahanan; dan (4) Menegakkan keadilan. Hal ini dilaksanakan melalui badan-badan peradilan.Sedangkan menurut Charles E. Merriam (Budiarjo, 2008: 56), menyebutkan lima fungsi negara, yaitu: keamanan ekstern, ketertiban intern, keadilan, kesejahteraan umum, dan kebebasan.

Ide dasar konsep negara kesejahteraan berangkat dari upaya negara untuk mengelola semua sumber daya yang ada demi mencapai salah satu tujuan negara yaitu meningkatkan kesejahteraan rakyatnya. Cita-cita ideal ini kemudian diterjemahkan dalam sebuah kebijakan yang telah dikonsultasikan kepada publik sebelumnya dan kemudian dapat dilihat apakah sebuah negara betul-betul mewujudkan kesejahteraan warga negaranya atau tidak. Masalah kemiskinan dan kesehatan masyarakat merupakan sebagian dari banyak masalah yang harus segera direspons oleh pemerintah dalam penyusunan kebijakan kesejahteraan.

Menurut Barr (1998; dalam Simarmata, 2008:18), pembangunan ekonomi yang dilakukan oleh negara kesejahteraan haruslah berkorelasi dengan kemaslahatan dan kemakmuran rakyat. Prinsip ini menjadi tugas utama yang harus diwujudkan dalam negara kesejahteraan. Menurutnya, ada dua hal yang terkait langsung dengan upaya pembangunan ekonomi: Pertama, perwujudan negara kesejahteraan bukanlah sesuatu yang terpisah dari upaya pembangunan ekonomi. Seperti yang telah dinyatakan, pembangunan ekonomi harus membuat masyarakat semakin sejahtera, 
bukan sebaliknya. Kedua, tujuan perwujudan negara kesejahteraan bukan hanya karena alasan kesamaan (equality), tetapi juga demi efisiensi dalam proses ekonomi. Idealnya, alasan kesamaan atau pemerataan tidak bertentangan dengan tujuan efisiensi dalam ekonomi. Dua hal ini menjadi bagian dari tujuan-tujuan kesejahteraan. Dalam mendesain sebuah negara kesejahteraan, ada dua pertanyaan penting yang harus digarisbawahi, yaitu: Pertama, apa tujuan dari sebuah kebijakan?, dan Kedua, Dengan metode apa tujuan tersebut dapat dicapai?. Dua pertanyaan ini paling tidak dapat menjelaskan apakah sebuah kebijakan suatu negara betul-betul berupaya mewujudkan kesejahteraan rakyat atau tidak.

\section{Beberapa Ciri dan Model Negara Kesejahteraan (Welfare State)}

Terdapat beberapa ciri dan model dari negara kesejahteraan. Menurut Goodin (1999:4) negara kesejahteraan (wvelfare state) bukan hanya satu bentuk saja, tetapi memiliki banyak ragam program dan kebijakan (programmes and policies) dan kombinasi yang berbeda. Secara detail, ada beragam model negara kesejahteraan yang sudah berkembang, khususnya di negara-negara maju di Eropa dan Amerika. Perbedaan model negara kesejahteraan biasanya dikarenakan perbedaan penekanan tujuan dalam kebijakan setiap negara, yang disesuaikan dengan kondisi, situasi, dan realitas yang mereka hadapi.

Menurut Goodin (1999; dalam Simarmata, 2008: 19) negara kesejahteraan sering diasosiasikan dengan proses distribusi sumber daya yang ada kepada publik, baik secara tunai maupun dalam bentuk tertentu (cash benefits or benefits in kind). Konsep kesejahteraan juga terkait erat dengan kebijakan sosial-ekonomi yang berupaya untuk mewujudkan kesejahteraan rakyat secara umum. Beberapa bidang yang paling mendesak untuk diperhatikan dalam kebijakan kesejahteraan adalah masalah pendidikan, kesehatan dan penyediaan lapangan kerja.

Selanjutnya Barr (1998; dalam Simarmata, 2008: 19-20) mengidentifikasibeberapa hal penting ketika kita bicara mengenai peran negara kesejahteraan. Beberapa hal itu adalah:

Pertama, bahwa sumber kesejahteraan masyarakat tidak hanya berasal dari negara. Sumber kesejahteraan masyarakat bisa berasal dari: (1) Kesejahteraan masyarakat dapat mengalir lewat gaji atau pemasukan (income) dari tempat di mana ia 
bekerja. Gaji yang layak dan aturan pekerjaan yang manusiawi dapat membawa waarga pada kehidupan yang sejahtera. Selain itu, adanya jaminan ketika mereka menghadapi masa sulit, seperti sakit atau di-PHK juga menjadi ukuran penting bagi kesejahteraan masyarakat; (2) Adanya kemampuan untuk menyisihkan sebagian dari pendapatannya juga menjadi ukuran kesejahteraan warga negara. Kemampuan itu dimungkinkan bila mereka sudah mendapatkan gaji yang lebih dari cukup. Bagaimana mungkin mereka dapat menabung atau membuat asuransi secara pribadi ketika gaji yang mereka terima sangat jauh dari cukup. Karenanya, kelayakan gaji menjadi pengandaian bagi inisiatif untuk menyisihkan sebagian dari penghasilannya; (3) Selain itu, sumber kesejahteraan juga bisa datang dari donasi warga yang lebih mampu secara sukarela. Pemberian sukarela ini memang tidak hanya dalam bentuk uang. Ia bisa saja diberikan dalam bentuk penjualan barang di bawah harga pasar atau memberikan tambahan waktu libur kepada para pekerja; dan(4) Sementara peran negara bagi perwujudan kesejahteraan datang lewat kebijakan pemberian uang tunai atau dalam bentuk tertentu (cash benefits or benefits in kind).

Kedua, yang patut diperhatikan dalam sistem negara kesejahteraan adalah bahwa cara penyampaian (modes of delivery) sumber daya kesejahteraan juga beragam. Menurutnya, penyampaian manfaat kesejahteraan itu, misalnya, bisa dilakukan dengan cara memberikan pelayanan gratis (seperti pelayanan kesehatan tanpa biaya) atau memberikan uang lewat peringanan pajak, dan sebagainya.

Ada beberapa alasan mengapa suatu pemerintahan memiliki sistem negara kesejahteraan. Alasan-alasan tersebut menjadi tujuan sekaligus juga menjadi alat ukur kesuksesan dalam menjalankan sistem negara kesejahteraan. Menurut Goodin (1999:22), terdapat enam hal yang dijadikan sebagai alasan mengapa memilih negara kesejahteraan, yaitu: Pertama, adalah untuk mempromosikan efisiensi ekonomi (promoting economic efficiency); Kedua, untuk mengurangi kemiskinan (reducing proverty); Ketiga, mempromosikan kesamaan sosial (promotingsocial equality); Keempat, mempromosikan integrasi sosial atau menghindari eksklusi sosial (promoting social integration and avoiding social exclusion) ; Kelima, mempromosikan stabilitas sosial (promoting social stability); dan Keenam, mempromosikan otonomi atau kemandirian individu (promoting autonomy). SementaraCommission on Social Justice menyebutkan ada Tujuh alasan mengapa alasan pentingnya negara kesejahteraan, yaitu: (1)Prevent poverty 
where possible and relieve it where necessary; (2) Protect people against risks arising in the labour market and from family; (3) change; (4) Redistribute resources from richer to poorer members of society; (5) Redistribute resources of time and money over people's life-cycles; (6)Encourage personal independence; dan (7)Promote social cohesion.

Secara umum, paling tidak terdapat tiga model utama tentang Negara Kesejahteraan (Simarmata,2008: 31-33). Ketiga model utama ini dapat dijabarkan secara sederhana, sebagai berikut:

Pertama, Model Liberal atau Residual (Anglo-Saxon) dengan ciri-ciri meliputi: (1) Dukungan sosial yang means-tested, atau terbatas, atau bersyarat, dan lebih berupa jaring pengaman; (2) Upaya negara yang lebih besar dipusatkan pada upaya menciptakan skema pembiayaan supaya warga negara dapat berpartisipasi (kembali) dalam arus besar ketenagakerjaan; dan (3) Secara sekaligus, pengembangan industri dan perdagangan dikembangkan terlebih dahulu (precursory) untuk menciptakan akses atas barang dan jasa, serta daya beli yang berkelanjutan.Contoh negara penganut model ini adalah: Amerika Serikat, Kaanada, dan Australia.

Kedua, Model Konservatif (Korporatis, Continental Europe) dengan ciri-ciri meliputi: (1) Negara mengusahakan skema kesejahteraan yang dikelola oleh negara; (2) Dalam produksi dan pengorganisasian, negara bukan satu-satunya pelaksana, melainkan juga kolaborasi warga negara/pekerja dengan sektor swasta, dan juga pajak negara yang dikaitkan dengan tunjangan tertentu; (3) Namun demikian, pajak dapat dikatakan tetap tinggi, yang ini terkait dengan pembiayaan secara meluas kebutuhankebutuhan warga negara, termasuk hal-hal yang tidak dapat dibiayai dengan kolaborasi warga negara/pekerja dan sektor swasta; dan (4) Arah dari skema kesejahteraan terutama membiayai kondisi-kondisi dimana warga negara "sakit" baik secara sosial (pengangguran, cacat, tua, dan sebagainya) maupun secara fisik (soal kesehatan), sehingga seringkali model ini disebut model proteksi sosial.Contoh negara penganut model ini adalah: Austria, Perancis, Jerman, dan Italia.

Ketiga, Model Sosial-Demokratis (Redistributif-Institusional) dengan ciri-ciri meliputi: (1) Satu skema pajak dipakai untuk membiayai keseluruhan pembiayaan skema kesejahteraan; (2) Skema kesejahteraan ini mencakup layanan yang menyeluruh dengan standar setinggi-tingginya, dan akses yang semudah-mudahnya (universal coverage), warga negara dianggap mempunyai hak atas pengaturan skema kesejahteraan 
(prinsip equity); dan (3) Kebijakan negara diarahkan pada integrasi industri dan perdagangan dengan skema-skema kesejahteraan itu.Contoh negara penganut model ini adalah negara-negara: Skandinavia, seperti: Swedia dan Norwegia.

Sementara, Esping-Andersen (Triwibowo \& Bahagijo, 2006:14) membagi tipologi negara kesejahteraan kedalam tiga bentuk, yakni: (1) Residual welfare state, yang meliputi negara seperti Australia, Kanada, Selandia Baru, dan Amerika Serikat, dengan basis rezim kesejahteraan liberal dan dicirikan dengan jaminan sosial yang terbatas terhadap kelompok target yang selektif serta dorongan yang kuat bagi pasar untuk mengurus pelayanan publik; (2) Universal Welfare State, yang meliputi negara seperti Denmark, Finlandia, Norwegia, Swedia, dan Belanda, dengan basis rezim kesejahteraan dmokrat dab dicirikan dngan cakupan jaminan sosial yang universal dan kelompok target yang luas serta tingkat dekomodifikasi yang ekstenfif; dan (3) Social Insurance Welfare State, yang meliputi negara seperti Australia, Belgia, Perancis, Jerman, Italia, dan Spanyol dengan basis rezim kesejahteraan konservatif dan dicirikan dengan sistem jaminan sosial yang tersegmentasi serta peran penting keluarga sebagai penyedia pasok kesejahteraan.

\section{Landasan Filosofis-Politik Negara Kesejahteraan}

Gagasan tentang Negara kesejahteraan (welfare state) sendiri tampil sebagai sebuah discursive practice sejak pertengahan abad ke-20.Sebagaimana dikatakan Myles dan Quadagno (2002: 34), bahwa pada dekade tahun 1970-an studi kontemporer tentang negara kesejahteraan modern mendapatkan banyak perhatian, baik dari kalangan sejarawan (bistorians), ilmuwan politik (political scientists), dan ilmuwanilmuwan sosial lainnya.

Menurut Hobsbawn (dalam Simarmata, 2008: 349), implementasi terhadap gagasan tersebut merupakan cerminan dari proses perkembangan demokrasi dan kapitalisme terutama di Eropa, dimana kehadirannya tidak dapat dilepaskan dari proses negosiasi politik antara artikulasi perjuangan politik kalangan kiri dan kelas pekerja dengan perkembangan formal social kapitalisme. Benturan-benturan antara kelas pekerja dan modal berhasil didamaikan dengan terbangunnya common platform penataan Negara berbasis welfare state.Platform tersebut terwujud dalam berbagai program-program seperti pemenuhan berbagai kebutuhan mendasar manusia (basic 
buman needs) oleh Negara pada bidang pendidikan, perawatan kesehatan, penyediaan perumahan yang layak, perawatan untuk anak-anak, pemenuhan kebutuhan ekonomi bagi mereka yang lanjut usia, pengangguran maupun mereka yang memiliki kekurangan fisik. Beberapa program-program Negara kesejahteraan telah diakomodasi oleh perkembangan Negara di Eropa sejak abad ke-19 (Moon, 2004; dalam Simarmata, 2008: 349).

Menurut Esping-Anderson (Simarmata, 2008: 349-350), ketika kita menelaah prinsip-prinsip utama dari bentuk Negara kesejahteraan yang terdiri atas: Pertama, pengakuan terhadap hak-hak social yang melekat pada tiap-tiap warganegara (social citizenship); Kedua, demokrasi yang menyeluruh (full democracy); Ketiga, relasi system social-ekonomi berbasis industry modern; Keempat, hak untuk mendapatkan pendidikan dengan perluasan system pendidikan modern secara massif. Keempat prinsip tersebut menegaskan tentang bagaimana Negara kesejahteraan berdiri diatas fondasi pentingnya peran Negara untuk menjalankan prinsip-prinsip keadilan social, solidaritas dan kesetaraan diatas landasan formal social masyarakat kapitalistik.

Meskipun Negara kesejahteraan menempatkan pentingnya pemenuhan keadilan social melalui proses distribusi ekonomi dari Negara kepada rakyat, namun dengan merujuk pada empat prinsip asasi dari Negara kesejahteraan diatas, tidak membuat welfare state abai terhadap dinamika pasar bebas dan pentingnya efisiensi ekonomi. Negara kesejahteraan justru berpijak pada prinsip-prinsip keadilan social, demokrasi social yang memperjuangkan kesetaraan tiap-tiap warga Negara, pengutamaan manusia sebagai makhluk sosial, dan efisiensi ekonomi yang berbasis ekonomi pasar namun responsif terhadap keberlanjutan kehidupan publik.

Terdapat Empat prinsip umum dari Negara Kesejahteraan (Welfare State), yakni: (1) Prinsip Hak-Hak Sosial dalam Negara Demokrasi; (2) Prinsip Welfare Rights; (3) Prinsip Kesetaraan Kesempatan Bagi Warga Negara; dan (4) Prinsip Keseimbangan Otoritas Publik dan Ekonomi, dan Efisiensi Ekonomi. Ke-Empat prinsip umum dari Negara Kesejahteraan (Welfare State) memiliki relevansi dan sinergi dengan tujuan dari pembangunan negara Republik Indonesia.

Selanjutnya penjelasan tentang ke-Empat prinsip umum dari Negara kesejahteraan tersebut adalah sebagai berikut (Simarmata: 350-358): 
Pertama, Prinsip Hak-Hak Sosial dalam Negara Demokrasi. Seiring dengan trend gelombang pasang demokrasi liberal pasar bebas yang saat ini tengah berkibarkibar di seluruh dunia, faham demokrasi tengah direduksi habis-habisan ke dalam aspek yang hanya bersifat teknis procedural.Adam Przeworski (1991) misalnya memaknai demokrasi sebatas system yang memfasilitasi penyelesaian konflik dapat dilakukan melalui cara-cara non-kekerasan.Sementara Larry Diamond (1993) memandang demokrasi telah terkonsolidasikan ketika setiap agensi-agensi politik sepakat dengan demokrasi sebagai satu-satunya aturan main yang sah.Pandangan demokrasi secara minimalis ini selain mereduksi makna demokrasi, juga telah meruntuhkan pandangan demokrasi substansial sebagai suatu political action untuk memperjuangkan kemuliaan warga Negara sebagai pemilik sah kedaulatan politik.

Dalam diskursus demokrasi, seperti diuraikan oleh TH Mashall (1977), pembentukan Negara kesejahteraan merupakan salah satu pilar esensial dari Negara demokratik.Sehingga tidak ada Negara demokrasi tanpa hadirnya pemenuhan terhadap hak-hak sosial bagi tiap-tiap warganya. Dengan kata lain pemenuhan hakhak social dari warga Negara adalah inheren sebagai tanggungjawab Negara demokratik. Tatanan demokrasi dalam konteks ini tidak dapat direduksi hanya pada penataan aturan-aturan main prosedural politik untuk memilih pejabat publik. Pemenuhan hak-hak sosial dari warga Negara sejalan dengan tujuan substansial demokratik untuk memberikan pemenuhan standar kehidupan sosial masyarakat yang baik, sehingga ia dapat menggunakan hak-hak sipil dan politiknya secara utuh. Tujuan mendasar dari pengedepanan prinsip hak-hak sosial ini adalah agar warga Negara dapat mengaktualisasikan sepenuhnya segenap potensi kemampuan dirinya dan terhindar dari proses pemiskinan struktural.

Kedua, Prinsip Welfare Rights.Secara filosofis keberadaan wacana Negara kesejahteraan ditopang oleh ide filosofis tentang keadilan sosial terutama berhubungan dengan keadilan distributif.Kebijakan Negara kesejahteraan tidak serta merta memenuhi kebutuhan-kebutahan dari tiap-tiap individu, namun demikian kebijakan publik yang dilakukan oleh Negara kesejahteraan memiliki tujuan untuk mendistribusikan pendapatan secara adil bagi seluruh warga Negara.Salah satu aspek keadilan sosial yang ditekankan sebagai landasan filosofis dari Negara kesejahteraan adalah berhubungan dengan hak tiap-tiap warganegara untuk hidup secara layak 
(welfare rights). Konsepsi tentang welfare rights memandang bahwa hak-hak asasi manusia tidak cukup dipahami dalam pengertian negatif yang dipahami oleh kaum liberal seperti Isaiah Berlin (1969: 118-172) dalam Four Essays on Liberty (Kehidupan tiap-tiap manusia harus dijaga dari kemungkinan koersi dan intervensi dari kekuatan diluar dirinya), namun hak yang melekat dalam diri manusia juga harus dimaknai dalam pengertian positif sehubungan dengan pentingnya pemenuhan pada akses sumber-sumber daya yang penting bagi kehidupan manusia itu sendiri.

Prinsip pengakuan terhadap welfare rights menjaga agar tiap-tiap system hak kepemilikan yang diterapkan tidak merampas hak dari tiap-tiap orang maupun kelompok-kelompok social yang terpinggirkan kehilangangan akses sumber-sumber daya yang fundamental bagi kehidupan dirinya. Konsepsi welfare rights menjadi jangkar pengamatan agar hak-hak rakyat untuk mengakses sarana-sarana kehidupan yang esensial untuk dirinya tetap dapat dijamin. Sehingga prinsip common good (kebaikan bersama) yang mengikat kehidupan tiap warganegara tetap dapat dipertahankan. Prinsip welfare rights berpijak pada pemenuhan nilai-nilai fundamental kemanusiaan melalui program-program social untuk memenuhi hajat hidup layak bagi setiap warganegara.

Ketika kita memahami substansi keadilan sosial secara radikal, welfare rights sendiri merupakan hak yang secara esensial melekat dalam diri manusia. Dalam pengertian ini suatu masyarakat dapat dipandang sebagai masyarakat berkeadilan, ketika didalamnya hak-hak social tersebut telah terjamin sejalaan dengan jaminan terhadap hak-hak sipil dan politik. Hak bagi tiap-tiap orang untuk hidup secara layak merupakan bagan dari pre-political rights, dimana hak tersebut telah melekat dalam diri manusia sebelum ia masuk menjadi warga politik. Dalam konteks demikian maka kehidupan politik akan bermakna ketika tatanan politik (political order) bertugas untuk melayani dan merealisaasikan hak-hak tersebut. Sejalan dengan kerja politik tersebut, suatu masyarakat berkeadilan dinilai ketika ia mampu mewujudkan akses seluasluasnya bagi public agar tiap-tiap warganya dapat hidup secara layak.

Untuk menjamin hak-hak tersebut dapat diperoleh oleh tiap-tiap warganegara, maka diperlukan inisiatif aktif dan tanggung jawab pemerintah untuk menjaga dan merealisasikan pemenuhan hak-hak sosial tersebut. Kebutuhankebutuhan sosial mendasar bagi tiap-tiap orang seperti pendidikan yang layak, hak 
untuk memperoleh barang-barang publik seperti air dan listrik, layanan kesehatan, dan hak untuk bertempat tinggal dan memiliki rumah dan kebutuhan sosial lainnya menjadi orientasi utama dari tugas Negara untuk memperjuangkannya. Untuk merealisasikannya, maka mekanisme pajak progresif maupun system transfer pendapatan merupakan standar minimal yang dilakukan Negara kesejahteraan (welfare states).

Ketiga, Prinsip Kesetaraan Kesempatan Bagi Warga Negara.Landasan filosofis dari relevansi Negara kesejahteraan juga ditopang oleh basis keadilan social redistributive atas prinsip kesetaraan kesempatan bagi setiap warga Negara.Moon (2004:214) menggunakan konsep keadilan redistributif dari John Rawls untuk menjelaskan prinsip kesetaraan kesempatan bagi warga Negara dalam konstruk Negara kesejahteraan. Apabila dalam prinsip filosofis tentang welfare rights sebelumnya telah dibahas tentang hak-hak tiap-tiap orang untuk hidup layak yang menyangkut hak atas pendidikan, rumah, air serta listrik, dan lain-lain. Tiap-tiap warganegara untuk dapat hidup secara layak dan terjamin kebutuhan hidupnya juga harus memiliki akses dan pengalaman untuk meraih berbagai posisi dan karer sehubungan dengan keberadaan lapangan kerja yang ada di masyarakat.

Seseorang ketika lahir dan tumbuh telah terikat pada posisi kelasnya masingmasing.Dalam konteks ini tidak semua orang memiliki akses yang setara untuk bekerja sesuai dengan pilihannya masing-masing.Sehingga kehadiran Negara kesejahteraan berperan untuk mengatasi hambatan-hambatan social yang harus dihadapi oleh tiap-tiap orang berkaitan dengan posisi kelas mereka.Akses kepada pendidikan yang layak dan redistribusi asset-aset produktif sangat berperan dalam pemenuhan akses kepada pekerjaan yang layak.Sehubungan dengan pemenuhan kesempatan yang setara kepada setiap warga untuk dapat bekerja secara layak ini bersifat kontekstual bagi setiap Negara. Formasi sosial yang eksis di tiap-tiap Negara menentukan formulasi seperti apa yang cocok dalam implementasinya. Dalam kecenderungan masyarakat agraris yang dominan seperti di Indonesia misalnya, dimana akses kepada tanah menjadi fundamental agar mereka dapat hidup secara layak, maka desain reformassi agrarian yang berkeadilan menjadi salah jalan utama untuk mewujudkan kesetaraan akses bagi tiap-tiap warga Negara. 
Keempat, Prinsip Keseimbangan Otoritas Publik dan Ekonomi, dan Efisiensi Ekonomi.Seiring dengan kemenangan rezim pengetahuan demokrasi liberal-pasar bebas, muncul pandangan yang saat ini menjadi wacana hegemonik tentang keutamaan pasar bebas dalam ruang public.Dalam paradigm neo-liberal masyarakat dipahami sebagai kumpulan jumlah individu-individu, sehingga upaya untuk memenuhi kepentingan masyarakat dijalankan dengan memenuhi kebutuhan agregatif dari tiap-tiap orang. Dalam pandangan kaum neo-liberal, institusi pasar bebas tempat proses transaksi jual beli berlangsung merupakan institusi utama yang harus ditegakkan agar tiap-tiap orang akan dapat terpenuhi kebutuhan dirinya.

Negara kesejahteraan berangkat dari pemahaman yang berbeda.Dalam pandangan filosofis Negara kesejahteraan, pasar bebas tidak dapat dibiarkan berjalan sendirian untuk mengatur kompleksitas kehidupan publik.Pada kenyataannya mekanisme pasar bebas tidak dapat menentukan prioritas sosial dan menanggulangi persoalan-persoalan kemiskinan dan ketidakadilan sosial.Ketika mekanisme pasar bebas dibiarkan berjalan tanpa batasan dan regulasi, justru semakin memperlebar jurang ketimpangan sosial, kemiskinan dan ketidakadilan. Prinsip mengejar kepentingan diri seluas-luasnya dalam arena pasar bebas, hanya akan mengakomodasi mereka yang dapat membayar dan memberi keuntungan dalam transaksi ekonomi yang diakui untuk mendapatkan fasilitas bagi kenyamanan hidupnya. Alih-alih bersikap egalitarian karena dapat memuaskan kepentingan tiap-tiap individu, mekanisme pasar bebas justru menjadi kerangka institusional yang berperan untuk mengekslusi setiap kepentingan dari mereka yang paling terpinggirkan secara ekonomi.

Secara lebih jauh pengedapanan rezim pasar bebas tanpa mempersiapkan perangkat regulasi yang tepat diatur oleh otoritas public, hanya akan menghancurkan fondasi dasar kehidupan publik yang berangkat dari ikatan relasi sosial. Sistem pasar bebas buta terhadap agenda prioritas dari kepentingan-kepentingan bersama. Keuntungan yang dihasilkan memberikan pertumbuhan dan keuntungan material, namun dalam jangka panjang, sistem pasar bebas yang berjalan eksesif tanpa batasan hanya akan menghancurkan ikatan-ikatan sosial yang mengintegrasikan kehidupan bersama dalam ruang publik. Prinsip kebaikan bersama akan hancur digerus oleh prinsip pasar bebas yang berlandaskan efisiensi ekonomi dan kepentingan diri. 
Kondisi ini sejak awal telah diperingatkan oleh founding father sistem kapitalisme yaitu Adam Smith. Bagi Smith mekanisme mekanisme pasar bebas dengan sendirinya akan sangat berbahaya bagi tatanan publik, ketika masing-masing orang hanya mengejar kepentingan egoistik dirinya sendiri. Institusi pasar bebas memerlukan topangan karakter solidaritas dan kepercayaan yang bersumber dari semangat komunitas, agar baik penjual dan pembeli dapat duduk bersama secara setara dalam proses transaksi pasar. Masyarakat Eropa abad ke-18 jaman disaat Adam Smith hidup memperlihatkan spirit loyalitas, altruism dan solidaritas begitu besar yang tumbuh dari kehidupan komunitas masyarakat sipil yang sehat tengah tergerus oleh kolonisasi wilayah ekonomi berbasis pasar bebas ke dalam setiap wilayah kehidupan public.

Berbeda dengan rezim pengetahuan pasar bebas, paradigm welfare state menegaskan pentingnya peran Negara sebagai otoritas politik berperan sebagai agensi yang menggerakkan dan mengatur kehidupan publik. Pentingnya Negara dalam prinsip welfare state tidak ditempatkan untuk menggusur peran pasar bebas, namun Negara menjadi penting guna mendorong agar pasar bebas dapat berfungsi dengan baik dan tidak meminggirkan kepentingan bersama. Dengan demikian yang menjadi perhatian dari penyeru welfare state bukanlah pengedepanan peran Negara diatas pasar, namun yang paling penting adalah bagaimana menempatkan keterlibatan pasar maupun Negara secara tepat untuk menggerakkan kehidupan publik.

Menurut Triwibowo dan Bahagijo (2006:21), berangkat dari pengakuan terhadap pentingnya baik otoritas pasar maupun Negara, desain Negara kesejahteraan secara filosofis justru tidak menghalangi prinsip efisiensi ekonomi. Negara kesejahteraan justru bermaksud menggerakkan roda perekonomian secara positif untuk mendorong agar setiap sumber daya manusia dimanfaatkan secara produktif untuk menggerakkan aktivitas ekonomi, dengan memenuhi kebutuhan dasar dari tiap-tiap orang.Selanjutnya prinsip Negara kesejahteraan juga berniat untuk mendorong partisipasi penuh pada pasar tenaga kerja maupun aktivitas investasi dan menabung.

\section{Kesimpulan}


Negara Kesatuan Republik Indonesia, sebagaimana diamanatkan dalam Undang-Undang Dasar 1945, didesain sebagai Negara Kesejahteraan (welfare state).Negara Kesejahteraan (welfare state) secara singkat didefinisikan sebagai suatu negara dimana pemerintahan negara dianggap bertanggung jawab dalam menjamin standar kesejahteraan hidup minimum bagi setiap warga negaranya.Secara umum suatu negara bisa digolongkan sebagai negara kesejahteraan jika mempunyai empat pilar utamanya, yaitu: (1) social citizenship; (2) full democracy; (3) modern industrial relation systems; dan (4) rights to education and the expansion of modern mass educations systems. Keempat pilar ini dimungkinkan dalam negara kesejahteraan karena negara memperlakukan penerapan kebijakan sosial sebagai penganugerahan hak-hak sosial (the granting of social rights) kepada warganya. Hak-hak sosial tersebut mendapat jaminan seperti layaknya hak atas properti, tidak dapat dilanggar (inviolable), serta diberikan berdasar basis kewargaan (citizenship) dan bukan atas dasar kinerja atau kelas.

Terlepas dari ideologinya, setiap negara menyelenggarakan beberapa minimum fungsi yang mutlak perlu, yaitu: (1) Melaksanakan penertiban (law and order); (2) Mengusahakan kesejahteraan dan kemakmuran rakyatnya; (3) Pertahanan; dan (4) Menegakkan keadilan.

Terdapat enam hal yang dijadikan sebagai alasan mengapa memilih negara kesejahteraan, yaitu: Pertama, adalah untuk mempromosikan efisiensi ekonomi (promoting economic efficiency); Kedua, untuk mengurangi kemiskinan (reducing proverty); Ketiga, mempromosikan kesamaan sosial (promotingsocial equality); Keempat, mempromosikan integrasi sosial atau menghindari eksklusi sosial (promoting social integration and avoiding social exclusion) ; Kelima, mempromosikan stabilitas sosial (promoting social stability); dan Keenam, mempromosikan otonomi atau kemandirian individu (promoting autonomy).

Secara umum, paling tidak terdapat tiga model utama tentang Negara Kesejahteraan, yakni: Model Liberal atau Residual (Anglo-Saxon), Model Konservatif (Korporatis, Continental Europe), dan Model Sosial-Demokratis (RedistributifInstitusional). Terdapat Empat prinsip umum dari Negara Kesejahteraan (Welfare State), yakni: (1) Prinsip Hak-Hak Sosial dalam Negara Demokrasi; (2) Prinsip Welfare Rights; 
(3) Prinsip Kesetaraan Kesempatan Bagi Warga Negara; dan (4) Prinsip Keseimbangan Otoritas Publik dan Ekonomi, dan Efisiensi Ekonomi.

\section{Daftar Pustaka}

Barr, Nicholas. 1998. The Economics of the Welfare State. California: Stanford University Press.

Budiardjo, Miriam. 2008. Dasar-Dasar Ilmu Politik (edisi reevisi). Jakarta: Gramedia.

Esping-Andersen, G. 1990. The Three Worlds of Welfare Capitalism. Princeton: Princeton University Press.

Goodin, Robert E. 1999. The Real Worlds of Werfare Capitalism. Cambridge: Cambridge University Press.

Myles, John; \& Quadagno, Jill. 2002. Political Theories of the Welfare State. Social Service Review, Vol. 76, No. 1, 75th Anniversary Issue (March 2002). Pp. 34-57.

Pierson, Christopher. 2007. Welfare State: The New Political Economy of Welfare. Pennsylvania: The Pennsylvania State University Press.

Simarmata, Henry T. 2008. Negara Kesejahteraan dan Globalisasi: Pengembangan Kebijkan dan Perbandingan Pengalaman. Jakarta: PSIK Universitas Paramadina.

Suharto, Edi (1997), Pembangunan, Kebijakan Sosial dan Pekerjaan Sosial:Spektrum Pemikiran, Bandung: LSP Press.

Suharto, Edi (2005a), Membangun Masyarakat Memberdayakan Rakyat: Kajian Strategis Pembangunan Kesejabteraan Sosial dan Pekerjaan Sosial, Bandung: Refika Aditama.

Suharto, Edi (2005b), Analisis Kebijakan Publik: Panduan Praktis Mengkaji Masalabdan Kebijakan Sosial, Bandung: Alfabeta.

Suharto, Edi (2006a), "Peta dan Dinamika Welfare State di Beberapa Negara:Pelajaran Apa Yang Bisa Dipetik Untuk Membangun Indonesia?”, makalah disampaikan pada Seminar Mengkaji Ulang Relevansi Welfare State dan Terobosan melalui Desentralisasi-Otonomi di Indonesia, Institute for Research and Empowerment (IRE) Yogyakarta dan Perkumpulan PrakarsaJakarta, 
bertempat di Wisma MM Universitas Gadjah Mada, Yogyakarta 25 Juli 2006.

Triwibowo, Darmawan; \& Bahagijo, Sugeng. 2006. Mimpi Negar Kesejahteraan. Jakarta: LP3ES. 